\title{
Produktivitas Ayam Petelur Fase Layer II dengan Pemberian Pakan Free Choice Feeding
}

\author{
(Productivity of Laying Hens II Phase with Free Feeding Choice) \\ Auliya Chanifuddin Luthfi, Suhardi, Eudia Christina Wulandari \\ Program Studi Peternakan, Fakultas Peternakan, Universitas Boyolali, Boyolali, 57313 \\ Email Penulis Korespondensi : eudia1990.christina@gmail.com
}

\begin{abstract}
ABSTRAK
Penelitian ini bertujuan untuk mengetahui kebutuhan nutrisi ayam petelur sesuai dengan kondisi fisiologis dan lingkungan guna menunjang produktivitas ayam ras petelur melalui pemberian pakan secara free choice feeding. Materi yang digunakan yaitu ayam ras petelur yang berumur 52 minggu sebanyak 30 ekor. Perlakuan yang diberikan yaitu ternak diberi pakan secara bebas pilih dengan bahan pakan premix, jagung, bekatul, dan konsentrat yang diberikan secara ad libitum terukur. Parameter yang diukur adalah konsumsi ransum, Hen Day Production, tebal dan berat cangkang, indeks putih telur, indeks kuning telur, dan indeks haugh. Hasil penelitian dianalisis secara kuantitatif melalui pembacaan data dengan grafik. Hasil penelitian menunjukkan bahwa konsumsi ransum ayam petelur lebih rendah jika dibandingkan standar konsumsi pakan, yaitu berkisar antara $92-127$ g/ekor/hari dengan rata-rata konsumsi sebesar 109 g/ekor/hari, namun demikian kebutuhan nutriennya dapat terpenuhi karena kandungan nutrisi bahan pakannya baik. Hal tersebut dapat dilihat dari tingginya HDP, berat dan tebal cangkang, serta indeks telur yang baik. Berdasarkan hasil tersebut disimpulkan bahwa ayam petelur fase layer II yang diberi pakan secara free choice feeding lebih banyak mengonsumsi energi guna mencapai produksi yang maksimal.
\end{abstract}

Kata Kunci: Ayam petelur, Free choice feeding, HDP, indeks putih telur, indeks kuning telur, indeks haugh. (Ayam petelur, Free choice feeding, layer fase II, produktivitas)

\section{ABSTRACT}

This study aim to determine the nutritional needs of laying hens according to physiological and environmental conditions in order to support the productivity of laying hens with free feeding choice. Thirty layers of laying hens, age 52 weeks used in this study. The chickens were fed freely selectively with premix, corn, rice bran, and concentrate feed as measured ad libitum. Parameters measured were consumption, HDP, shell thickness and weight, albumen index, yolk index, and haugh index. The results were analyzed quantitatively by reading data with the graph. The results showed that the consumption of laying hen rations is lower than the standard of feed consumption, which is ranging from $92-127 \mathrm{~g} /$ tail / day with an average consumption of $109 \mathrm{~g} /$ tail / day. However, the nutrient needs can be met because the nutrient content of feed ingredients is good. This can be seen from the height of the HDP, the weight and thickness of the shell, as well as the good egg index. Finally, it was concluded that 
layer II laying hens that are fed free choice feeding consume more energy to achieve maximum production.

Keywords: Laying hens, Free feeding choice, HDP, albumen index, yolk index, haugh index. (Laying hens, Free choice feeding, phase II layer, productivity)

\section{PENDAHULUAN}

Ayam petelur mempunyai tahap periode pertumbuhan dari fase starter, fase grower, dan fase layer. Ayam petelur fase layer adalah ayam dewasa yang sedang menjalani masa bertelur atau berproduksi (Purwaningsih, 2014). Lama masa produksi ayam petelur yaitu 80 - 90 minggu. Produksi akan meningkat pada saat ayam berumur 22 minggu dan mencapai puncaknya pada umur 28-30 minggu, kemudian produksi telur menurun dengan perlahan sampai $55 \%$ setelah umur 82 minggu (Maharani et al., 2013).

Ayam petelur sensitif terhadap cuaca panas dan keributan, suhu tubuh normal ayam petelur yaitu antara $39-41^{\circ} \mathrm{C}$ (Tandil dan Indarsih, 2020). Zona nyaman untuk pemeliharaan ayam petelur yaitu pada lingkungan dengan suhu $10-20^{\circ} \mathrm{C}$ (Yuwanta, 2004). Ayam petelur yang dipelihara dalam kandang dengan temperatur lingkungan di atas titik kenyamannya akan memberikan reaksi seperti meningkatkan heat loss dengan cara panting, meningkatkan konsumsi minum, menurunkan konsumsi pakan dan produksi akan menurun karena konsumsi pakan menurun, sehingga zat-zat pakan yang masuk ke dalam tubuh hanya sedikit, di samping itu zat pakan yang terbatas akan digunakan untuk menjaga keseimbangan panas tubuh sehingga produksi menjadi terbatas (Muharlien et al., 2017).

Selain faktor lingkungan, faktor pakan dapat mempengaruhi tingka produktivitas ayam petelur. Menurut SNI (2014) bahwa standar ransum pakan ayam petelur periode layer yaitu kadar air maksinal $14 \%$, protein kasar minimal 16\%, lemak kasar 2,5 - 7\%, kalsium 3,25 - 4\%, fosfor $0,6-1,0 \%$, lysine
$0,8 \%$, metionin $0,35 \%$ dan energi metabolis $2.650 \mathrm{kkal} / \mathrm{kg}$. Jika energi pakan saat fase layer terlalu rendah (kurang dari 2.600 kkal), konsumsi pakan lebih banyak sehingga Feed Convertion Ratio (FCR) meningkat dan efisiensi pakan menurun. Sebaliknya jika energi pakan terlalu tinggi akan terjadi penurunan konsumsi (Marzuki dan Rozi, 2018).

Suhu di Indonesia saat ini rata - rata sudah mencapai angka $30^{\circ} \mathrm{C}$ (Badan Pusat Statistik, 2019). Peningkatan suhu yang semakin panas dapat mempengaruhi performa produksi ayam petelur. Hal tersebut disebabkan karena ketika suhu lingkungan tinggi ayam akan membutuhkan energi yang lebih banyak untuk pengaturan suhu tubuhnya, sehingga ketersediaan energi untuk produksi telur berkurang. Pemenuhan kebutuhan nutrisi pada ternak merupakan salah satu bentuk dari upaya menyejahterakan ternak sehingga produktivitas dapat tercapai optimal. Salah satunya upaya tersebut yaitu sistem free choice feeding dimana ternak dapat memilih berbagai bahan pakan sesuai kebutuhan dan keinginannya. Pemberian pakan secara free choice feeding dapat digunakan untuk mengetahui kebutuhan ternak, selanjutnya akan dievaluasi produktivitas dengan standar kebutuhannya.

Tujuan dari penelitian ini adalah untuk mengetahui jumlah kebutuhan ayam petelur sesuai dengan kondisi fisiologis dan lingkungan guna menunjang produktivitas ayam ras petelur. Manfaat dari penelitian ini adalah untuk menjadi referensi dan rujukan bagi peternak, pabrik pakan maupun akademisi tentang kebutuhan pakan ayam ras petelur melalui free choice feeding pada suhu lingkungan saat ini. 


\section{MATERI DAN METODE}

\section{Materi Penelitian}

Materi yang digunakan di dalam penelitian yaitu ayam ras petelur jenis Lohman yang berumur 52 minggu sebanyak 30 ekor. Pakan yang diberikan berupa jagung giling, premik, konsentrat jadi, dan bekatul kandungan nutrisi yang disajikan dalam Tabel 1. Pakan diberikan secara bebas pilih. Peralatan yang digunakan berupa kandang battery, tempat pakan dan minum, timbangan digital dengan ketelitian 0,01 $\mathrm{g}$ untuk mengukur berat cangkang, mikrometer sekrup dengan ketelitian 0,01 mm utnuk mengukut ketebalan cangkang, jangka sorong untuk mengukur indeks telur, egg tray, gelas plastik, plastik klip, pinset, kertas label, dan alat tulis. Kandang battery berupa kandang bertingkat 3 susun yang setiap tingkatnya terdiri dari 10 sekat kandang yang terukur suhu lingkungan serta kelembapannya. Setiap sekat kandang berisi 1 ekor ayam.

Tabel 1. Kadar Nutrisi Bahan Pakan

\begin{tabular}{|c|c|c|c|c|c|c|c|}
\hline Bahan pakan & Protein & SK & Lemak & $\mathrm{Ca}$ & $\mathrm{P}$ & Energi & BETN \\
\hline Jagung ${ }^{1}$ & 9,03 & 2,58 & 1,49 & 0,11 & 0,22 & 3100 & $85,2^{3}$ \\
\hline Bekatul $^{1}$ & 11,64 & 22,34 & 12,97 & 0,45 & 1,91 & 2680 & $45,35^{3}$ \\
\hline Konsentrat $^{2}$ & 32,5 & 8 & 2 & 9 & 0,5 & 2755 & $22,5^{3}$ \\
\hline
\end{tabular}

Keterangan : 1. Hasil berdasarkan analisis Siahaan et al. (2013)

2. Sumber PT. Japfa Comfeed Indonesia

3. Berdasarkan perhitungan dengan rumus Hartadi et al. (1986)

\section{Metode Penelitian}

Ternak diletakkan pada kandang battery yang telah disediakan tempat pakan dengan 3 sekat selama 30 hari. Ayam diberi pakan setiap hari dengan takaran yang sama dan pakan ditambah kembali ketika salah satu bahan pakan habis sebelum waktu yang telah ditentukan (ad libitum terukur). Pengambilan data pakan, yang meliputi data konsumsi dan sisa pakan dilakukan setiap hari selama penelitian. Pengukuran berat kerabang, ketebalan kerabang, dan besarnya yolk pada ayam petelur yang dilakukan pada minggu terahir selama 7 hari untuk mendapatkan 30 sample telur. Konsumsi ransum dapat dihitung dengan cara:

Konsumsi ransum $=$ JPD $($ gram $)$ - JPT $($ gram $)$

Keterangan :

JPD : Jumlah Pakan yang Diberikan

JPT : Jumlah Pakan yang Tersisa (Walukow et al., 2017).

Hen Day Production (HDP) dihitung dengan cara berikut :

Keterangan :

$$
\frac{\mathrm{JT}}{\mathrm{JA}} \times 100
$$

JT : Jumlah Telur

JA: Jumlah Ayam yang bertelur
Penimbangan berat cangkang dilakukan pada cangkang telur yang sudah dibersihkan dari putih dan kuning telur. Pengukuran ketebalan cangkang dilakukan terhadap cangkang telur ayam petelur yang sudah dihilangkan selaput dalamnya. Pengukuran dilakukan pada bagian ujung tumpul, tengah, dan ujung runcing. Tebal kerabang telur dihitung dengan rumus :

$$
\text { Tebal kerabang }=\frac{\mathrm{t} 1+\mathrm{t} 2+\mathrm{t} 3}{3}
$$

Keterangan :

$\mathrm{t} 1, \mathrm{t} 2, \mathrm{t} 3=$ tebal kerabang pada ujung tumpul, tengah, dan runcing.

Pengukuran indeks telur dilakukan dengan cara telur dipecah di atas permukaan datar kemudian diukur pada diameter panjang dan pendek putih telur lalu ditusuk menggunakan tusuk gigi pada bagian albumen. Bagian tusuk gigi yang basah dilakukan pengukuran tinggi putih telur menggunakan jangka sorong. Rumus indeks putih telur seperti yang digunakan Argo et al. (2013) sebagai berikut:

$$
\text { Indeks Putih Telur }=\frac{\mathrm{h}}{0,5(\mathrm{~d} 1+\mathrm{d} 2)}
$$

Keterangan: 
$\mathrm{h}=$ Tinggi putih telur

$\mathrm{d} 1$ = Diameter panjang putih telur

$\mathrm{d} 2=$ Diameter pendek putih telur

Indeks kuning telur dapat diukur dengan rumus sebagai berikut (Argo et al., 2013) sebagai berikut:

$$
\text { Indeks Kuning Telur }=\frac{\mathrm{h}}{0,5(\mathrm{~d})}
$$

Keterangan:

$\mathrm{h}=$ Tinggi kuning telur

$\mathrm{d}=$ Diameter panjang kuning telur

Perhitungan indeks haugh dilakukan dengan pengukuran tinggi albumen dan bobot telur. Telur ditimbang menggunakan timbangan digital kemudian dipecah dan ditusuk menggunakan tusuk gigi bagian albumen. Bagian tusuk gigi yang basah diukur tingginya menggunakan jangka sorong. Indeks haugh diukur dengan rumus Lestari et al. (2018) sebagai berikut :

Indeks Haugh = $100 \log \left(\mathrm{h}+7,57-1,7 W^{0,37}\right)$

Keterangan :

$\mathrm{h}=$ Tinggi putih telur kental

$\mathrm{W}=$ Berat telur utuh dalam gram

\section{HASIL DAN PEMBAHASAN}

\section{Konsumsi Pakan}

Data rata - rata konsumsi pakan pada ayam petelur Lohman fase layer kedua yang diberi pakan secara free choice feeding disajikan pada Ilustrasi 1.

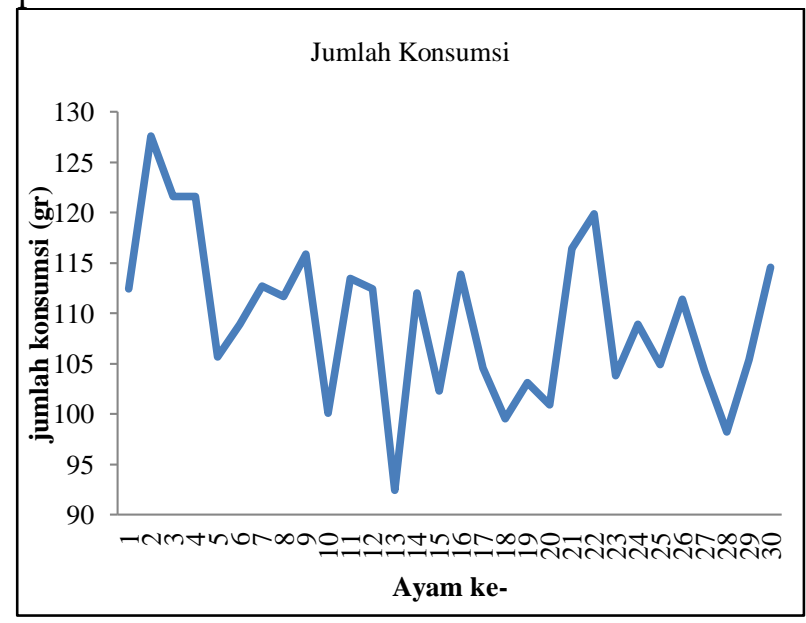

Ilustrasi 1. Konsumsi Ayam

Ilustrasi 1 menunjukkan bahwa konsumsi ayam selama penelitian berkisar antara 92 127 g/ekor/hari dengan rata-rata konsumsi sebesar 109 g/ekor/hari. Jumlah konsumsi tersebut masih di bawah standar konsumsi ransum ayam petelur. Menurut Afikasari et al. (2020) bahwa standar konsumsi pakan ayam petelur strain Lohman saat masa produksi berkisar antara 110 - 120 gram/ hari. Konsumsi pakan ayam petelur dipangaruhi oleh beberapa faktor. Zahra et al. (2012) menyatakan rendahya konsumsi pakan dapat dipengaruhi oleh beberapa hal yaitu usia, kualitas dan kuantitas pakan, serta bobot badan.

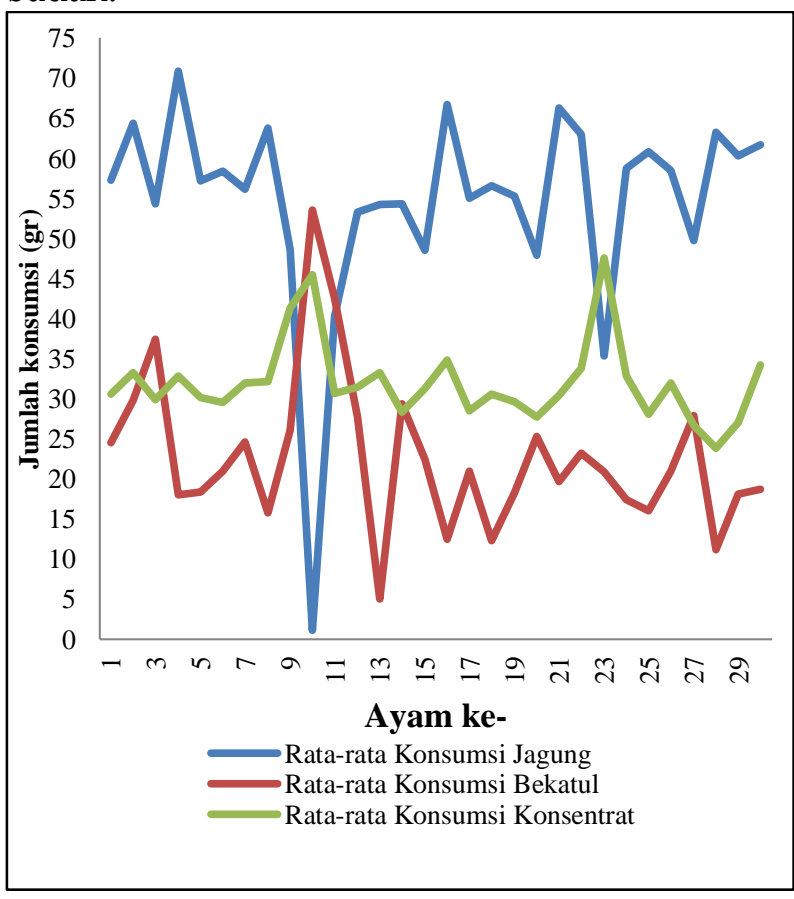

Ilustrasi 2. Konsumsi per-Bahan Pakan

Berdasarkan Ilustrasi di atas dapat diketahui bahwa rata-rata konsumsi jagung lebih tinggi dibandingkan konsentrat dan bekatul. Jagung mempunyai kandungan PK 9,03\% dan energi metabolis 3.100 Kkal, bekatul memiliki kadar PK 11,64\% dan energi $2.680 \mathrm{Kkal}$ (Siahaan et al., 2013), sedangkan konsentrat memiliki PK 32\% dan energi 2.755 Kkal (PT. Japfa Comfeed Indonesia). Hal tersebut mengakibatkan konsumsi energi pada ternak sudah tercukupi meskipun konsumsi pakannya hanya sedikit, yaitu berkisar antara 2800,11 - 3288,74 Kkal. Menurut Komalig et al. (2016) energi metabolis yang dibutuhkan ayam petelur pada masa produksi yaitu sekitar 2650 - 3000 Kkal. Dengan demikian dapat disimpulkan bahwa 
kebutuhan energi ayam sudah dapat terpenuhi sehingga konsumsi pakan jauh lebih rendah jika dibandingkan dengan standar. Huda et al. (2019) menyatakan bahwa ayam akan berhenti mengkonsumsi pakan ketika kebutuhan nutrisi dan energi untuk tubuhnya sudah dapat tercukupi.

Pakan yang digunakan yaitu konsentrat yang berasal dari PT. Japfa Comfeed dicampur bekatul dan jagung dengan standar peransuman $34 \%$ konsentrat, $16 \%$ bekatul, dan 50\% jagung. Berdasarkan Ilustrasi 2, dapat diketahui bahwa rata-rata konsumsi pakan ternak sedikit melebihi standar, yaitu bekatul 22,65 g dan jagung 54,72 g sedangkan konsentratnya hanya $31,99 \mathrm{~g}$.

\section{Hen Day Production (HDP)}

Hen Day Production ayam petelur umur 52 minggu selama penelitian berkisar antara $83-100 \%$. Hasil tersebut menunjukkan bahwa produksi telur masih sangat tinggi. Menurut Samadi et al. (2020) bahwa ayam umur 42 - 72 minggu yang memasuki fase layer II memiliki rata-rata produksi telur $72 \%$.

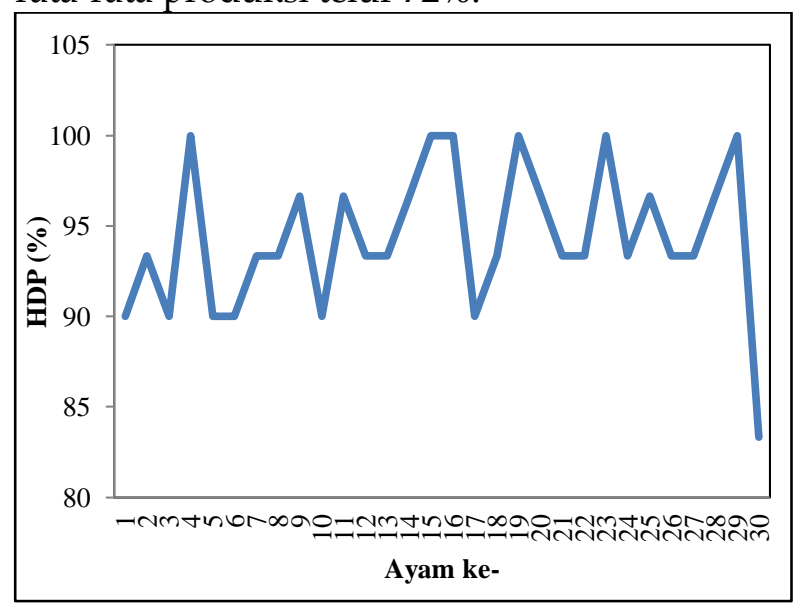

Ilustrasi 3. Hen Day Production

Tingginya HDP ayam selama penelitian dapat disebabkan karena tingginya konsumsi energi, yaitu antara 2800,11 - 3288,74 Kkal. Hal ini disebabkan karena perlakuan free choice feeding membuat ayam dapat memilih pakan yang disukainya. Ayam dalam penelitian ini lebih banyak mengkonsumsi pakan yang disukainya, yaitu jagung sebanyak 54,72 g, lebih tinggi jika dibandingkan konsumsi standar ayam petelur. Menurut Natsir et al. (2020) ayam secara naluri lebih menyukai pakan yang berbentuk butiran dibandingkan pakan mash atau tepung. Kandungan energi dalam jagung yang tinggi, yaitu 3.100 Kkal disertai konsumsi jagung yang tinggi membuat konsumsi energi yang masuk ke dalam tubuh juga tinggi. Zahra et al. (2012) menyatakan bahwa konsumsi energi yang tinggi dapat mencukupi kebutuhan energi ayam untuk metabolisme tubuh dan kebutuhan untuk produksi, jika didukung dengan kondisi lingkungan yang baik maka produksi akan berjalan dengan efisien. Varianti et al. (2017) menyatakan bahwa pemberian pakan dengan free choice feeding memberikan kebebasan ayam untuk memenuhi kebutuhan gizinya sendiri dengan mengandalkan kemampuan ayam untuk memilih dan mengkonsumsi bahan pakan yang disukainya. Hal tersebut membuat ayam merasa nyaman dan berkurang tingkat stressnya sehingga produktivitas ayam dapat optimal.

Kondisi lingkungan selama penelitian menunjukkan kondisi yang baik untuk ternak, yaitu dengan suhu berkisar antara $20,5-24,7^{\circ} \mathrm{C}$ dengan kelembapan $67-88 \%$. Kondisi lingkungan tersebut sudah sesuai dengan standar kenyamanan untuk ayam petelur. Menurut Priastoto et al. (2016) ayam petelur berada di kondisi yang nyaman pada suhu 18 - $24^{\circ} \mathrm{C}$. Suhu dan kelembapan lingkungan sangat berpengaruh terhadap produktivitas ayam petelur. Risnajati (2014) menyatakan bahwa kondisi fisiologi lingkungan yang terlalu tinggi dapat mengakibatkan ayam hanya mengkonsumsi pakan sesuai standar minimal kebutuhan hidup pokoknya, sehingga dapat mempengaruhi konversi pakan, bobot badan, produksi telur, dan bobot telur yang dihasilkan.

\section{Berat dan Tebal Cangkang Telur}

Berdasarkan Ilustrasi 4 dapat diketahui bahwa telur ayam hasil penelitian mempunyai berat cangkang berkisar antara 5,37 - 7,46 g dengan rata-rata sebesar 6,51 g. Hasil tersebut masih normal jika dibandingkan dengan hasil 
penelitian Harmayanda et al. (2016) yaitu antara $6,05-6,96 \mathrm{~g}$.

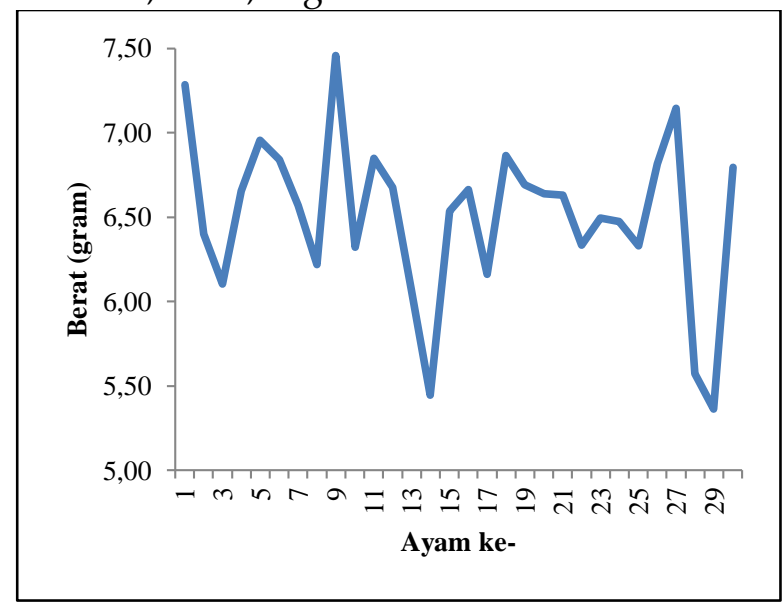

Ilustrasi 4. Berat Cangkang

Kualitas cangkang telur sangat dipengaruhi oleh konsumsi nutien pada ayam petelur. Widyantara et al. (2017) menyatakan bahwa berat cangkang telur dipengaruhi oleh kandungan nutrient ransum kerena cangkang telur tersusun atas 95\% kalsium karbonat dan sisanya adalah magnesium, fosfor, natrium, kalium, seng, besi, mangan, dan tembaga. Hasil ini dapat disimpulkan bahwa kandungan nutrisi dan konsumsi pakan sudah dapat memenuhi kebutuhan pembentukan telur dengan baik.

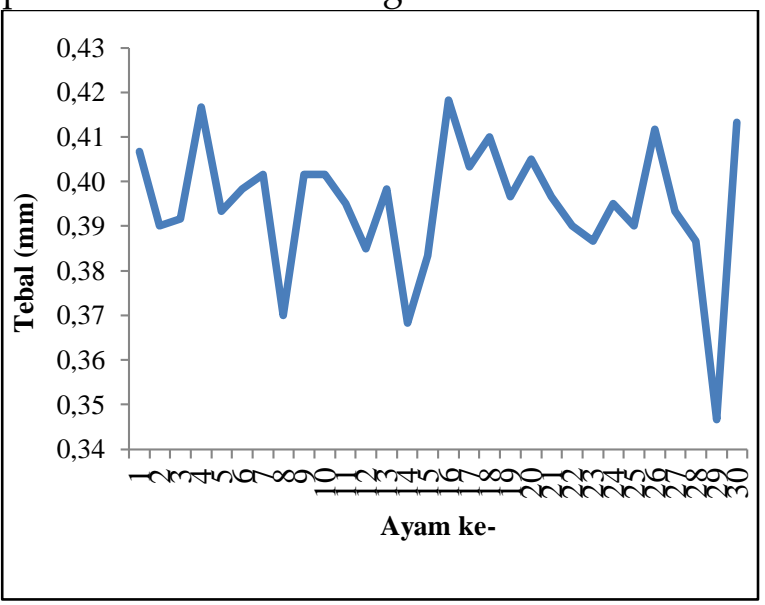

Ilustrasi 5. Ketebalan Cangkang

Berdasarkan Ilustrasi 5 diketahui bahwa telur ayam hasil penelitian mempunyai tebal cangkang berkisar antara 0,35-0,42 $\mathrm{mm}$. Hasil tersebut di atas standar yang dinyatakan oleh Widyantara et al. (2017) bahwa tebal cangkang telur yang dihasilkan oleh ayam strain Lohman normal yaitu antara 0,33 - 0,35 mm. Hasil ini menunjukkan bahwa konsumi pakan pada ayam sudah dapat memenuhi kebutuhan nutriennya untuk pembentukkan cangkang telur. Menurut Andrianto et al. (2019) bahwa ketebalan cangkang telur dipengaruhi oleh beberapa faktor, yaitu umur, jenis ayam, tingkat stress ayam, konsumsi nutrien, dan kesehatan ayam. Wulandari et al. (2012) menyatakan bahwa pemenuhan kebutuhan kalsium pada masa produksi sangat berpengaruh terhadap kualitas cangkang telur karena kandungan kalsium dan phosphor cangkang telur sangat dipengaruhi oleh jumlah kalsium dan phosphor yang diretensi dari pakan.

\section{Indeks Putih Telur}

Berdasarkan Ilustrasi 6 diketahui bahwa indeks putih telur berkisar antara 0,05 - 0,12. Indeks putih telur hasil penelitian masih termasuk dalam standar.

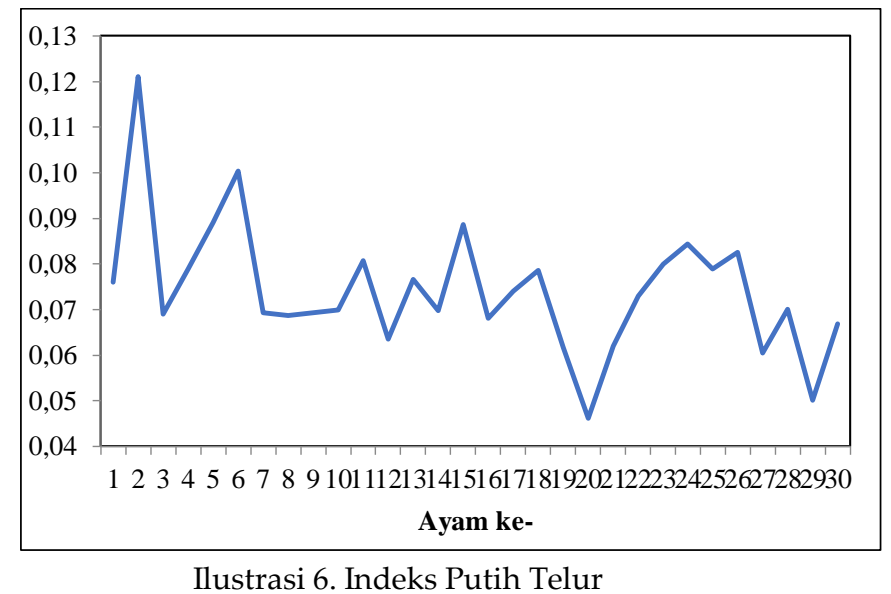

Telur ayam hasil penelitian termasuk dalam telur mutu II dan III. Menurut Standar Nasional Indonesia (2008) telur mutu I memliki indeks putih telur antara 0,134 0,175, mutu II antara 0,092 - 0,133, dan mutu III antara 0,05-0,091. Indeks putih telur yang rendah disebabkan karena konsumsi pakan konsentrat yang merupakan bahan pakan sumber protein sedikit, rata-rata yaitu 31,99 gram. Hal ini mengakibatkan konsumsi protein yang masuk ke dalam tubuh ternak juga sedikit. Wijaya et al. (2017) menyatakan bahwa indeks putih telur sangat dipengaruhi oleh kandungan protein dalam pakan, apabila konsumsi protein tinggi maka ovomucin 
(protein putih telur) yang terbentuk akan semakin banyak sehingga indeks telurnya pun akan semakin tinggi.

Berdasarkan indeks putih telur, perlakuan pemberian pakan secara free choice feeding sudah mampu memenuhi kebutuhan gizi ayam walaupun belum secara optimal. Hal tersebut dapat dilihat dari rendahnya nilai indeks putih telur, yang dapat diartikan bahwa ayam petelur sudah dapat memnuhi keutuhan protein untuk hidup pokok namun belum bisa secara maksimal memenuhi kebutuhan protein untuk produksi.

\section{Indeks Kuning Telur}

Berdasarkan Ilustrasi 7 diketahui bahwa indeks kuning telur berkisar antara 0,68-0,91. Telur hasil penelitian tersebut memiliki nilai indeks kuning telur yang di atas standar.

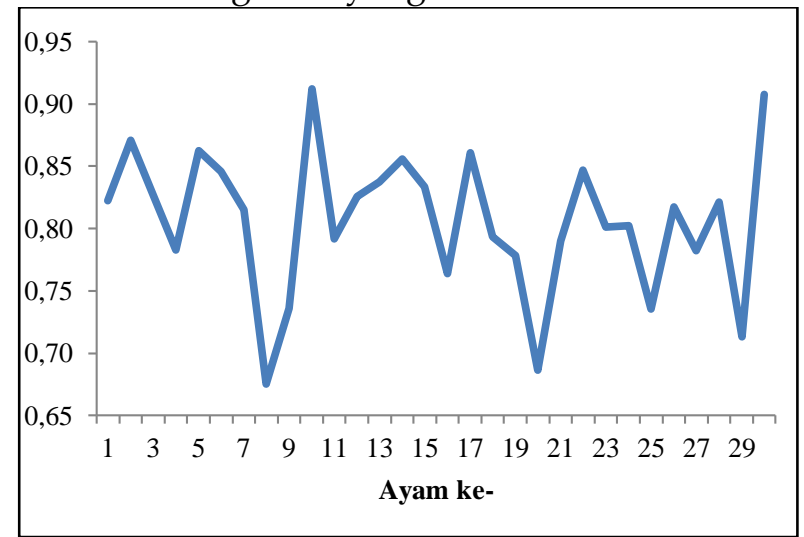

Ilustrasi 7. Indeks Kuning Telur

Jika dilihat dari indeks kuning telurnya, telur ayam hasil penelitian termasuk dalam telur mutu I. Menurut SNI (2008) bahwa nilai indeks kuning telur mutu I yaitu di antara 0,458 - 0,521, telur mutu II di antara 0,394 0,457, dan telur mutu III di antara 0,330 0,393 . Tingginya nilai indeks kuning telur pada telur hasil penelitian disebabkan karena konsumsi bekatul melebihi standar, rata-rata yaitu 22,65 g, padahal bekatul mempunyai kandungan lemak yang paling tingi. Hal ini menyebabkan konsumsi lemak oleh ternak cukup tinggi. Menurut Wijaya et al. (2017) bahwa indeks kuning telur dapat dipengaruhi oleh kandungan lemak, mineral, dan protein pada pakan yang dikonsumsi ternak. Argo et al. (2013) menyatakan bahwa berat kuning telur sangat dipengaruhi oleh lemak karena lemak adalah komposisi penyusun kuning telur terbanyak setelah air.

Berdasarkan indeks kuning telur, pemberian pakan dengan free choice feeding sudah mampu memenuhi kebutuhan nutrisi untuk ayam petelur. Hal tersebut dapat dilihat dari tingginya nilai indeks kuning telur yang dapat diartikan bahwa kebutuhan lemak dan energi ayam petelur sudah tercukupi.

\section{Indeks Haugh}

Berdasarkan Ilustrasi 8 diketahui bahwa indeks haugh telur berkisar antara 72,37 - 104,46. Telur ayam hasil penelitian memiliki nilai indeks haugh telur yang di atas standar.

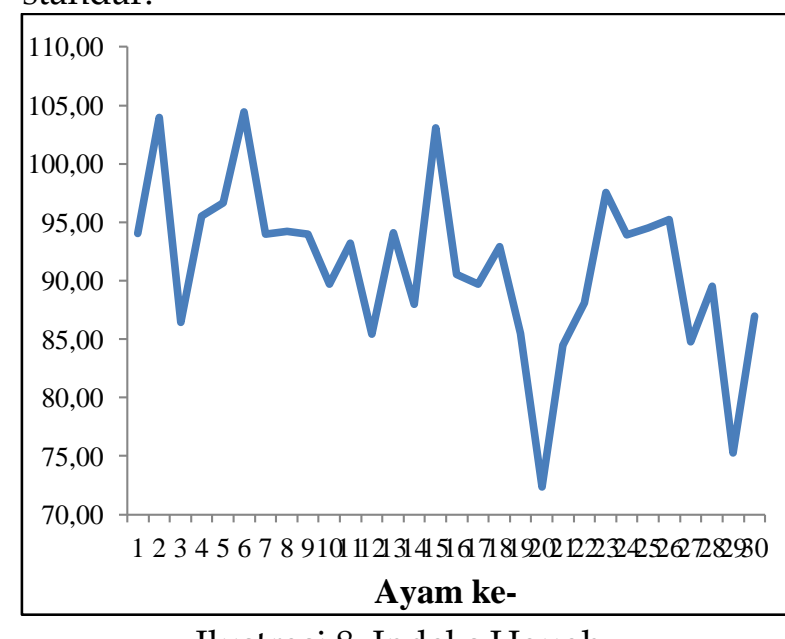

Ilustrasi 8. Indeks Haugh

Telur hasil penelitian termasuk dalam kualitas yang baik dengan nilai AA. Menurut Lestari et al. (2013) bahwa nilai haugh digunakan untuk menentukan kualitas telur dengan nilai kurang dari 31\% untuk kualitas C, $31-60 \%$ untuk kualitas B, $60-72 \%$ untuk kualitas A, dan di atas $72 \%$ untuk kualitas AA. Tingginya indeks haugh yang dihasilkan dipengaruhi oleh umur dari ayam dan kondisi lingkungan yang sesuai dengan zona kenyamanan ayam petelur. Hal tersebut sesuai Wijaya et al. (2017) bahwa indeks haugh dipengaruhi oleh umur, kualitas pakan yang diberikan, dan kondisi lingkungan yang cocok.

Berdasarkan indeks haugh, perlakuan pemberian pakan secara free choice feeding sudah mampu memenuhi kebutuhan gizi 
untuk ayam petelur. Hal tersebut dapat dilihat dari tingginya nilai indeks haugh yang berarti selama penelitian ayam petelur dapat menghasilkan telur dengan kualitas yang baik.

\section{KESIMPULAN}

Berdasarkan hasil penelitian ini dapat disimpulkan bahwa ayam petelur fase layer II yang diberi pakan secara free choice feeding lebih banyak mengonsumsi energi guna mencapai produksi yang maksimal. Meskipun demikian, kebutuhan nutrient yang lain juga dapat terpenuhi dengan baik. Hal tersebut dapat diketahui dari jumlah produksi telur per hari yang tinggi dan kualitas telur, meliputi berat cangkang, tebal cangkang, dan indeks telur (putih telur, kuning telur, dan haugh) yang baik.

\section{DAFTAR PUSTAKA}

Afikasari, D., Rifa'I, dan D. A. Candra. 2020. Pengaruh suplementasi probiotik melalui pakan terhadap konsumsi pakan ayam petelur strain Isa Brown. J. Ternak. 11 (1): 35 - 38

Andrianto, D. A., Sunaryo, dan O. R. Puspitarini. 2019. Pengaruh bio organik sumplemen (bos) terhadap bobot, indeks bentuk dan tebal kulit telur ayam Isa Brown di atas umur 64 minggu. J. Rekasatwa Peternakan. 2 (1): $60-65$

Argo, L. B., Tristiarti dan I. Mangisah. 2013. Kualitas fisik telur ayam arab petelur fase I dengan berbagai level Azolla microphylla. Anim. Agr. J. 2 (1): $445-457$

Badan Pusat Statistik. 2020. Kabupaten Boyolali dalam Angka 2020. BPS Kabupaten Boyolali.

Badan Standarisasi Nasional. 2008. Telur Ayam Konsumsi (SNI 3926 : 2008). Jakarta.

Badan Standarisasi Nasional. 2014. Peraturan Menteri Pertanian Nomor 31 /Permentan /Ot.140/2 /2014 tentang
Pedoman Budi Daya Ayam Pedaging Dan Ayam Petelur Yang Baik.

Harmayanda, P. O. A., D. Rosyidi, dan O. Sjofjan. 2016. Evaluasi kualitas telur dari hasil pemberian beberapa jenis pakan komersial ayam petelur. J. Pal. 7 (1): 25 32

Hartadi, H., S. Reksohadiprodjo, S. Lebdosukojo, dan A. D. Tillman. 1980. Tabel Komposisi Pakan untuk Indonesia. Gadjah Mada University Press, Yogyakarta

Huda, K.,W. P. Lokapirnasari, Soeharsono, S. Hidanah, N. Harijani, dan R. Kurnijasanti. 2019. Pengaruh pemberian probiotik Lactobacillus acidophilus dan Bifidobacterium terhadap produksi ayam petelur yang diinfeksi Escherichia coli. J. Sain. Pet. Ind. 14 (2) : $154-160$

Komalig, D. F., J. R. Leke, J. Laihad, dan C. Sarajar. 2016. Penggunaan tepung limbah labu kuning dalam ransum terhadap penampilan produksi ayam ras petelur. J. Zootek. 36 (2): $342-352$

Lestari, L., S. M. Mardiati dan M. A. Djaelani. 2018. Kadar protein, indeks putih telur, dan nilai haugh unit telur itik setelah perendaman ekstrak daun salam (Syzygium polyanthum) dengan waktu penyimpanan yang berbeda pada suhu $4^{\circ}$ C. Bul. Anat. Fis. 3 (1): 39-45

Lestari, S., R. Malaka, S. Garantjang. 2013. Pengawetan telur dengan perendaman ekstrak daun melinjo (Gnetum gnemon linn). J. Sains \& Teknologi. 13 (2): $184-$ 189

Lutfiana, K., T. Kurtini dan M. Hartono. 2015. Pengaruh pemberian probiotik dari mikroba lokal terhadap gambaran darah ayam petelur. J. Il. Pet. Ter. 3 (3): 151 156

Maharani, P., N. Suthama dan H. I. Wahyuni. 2013. Massa kalsium dan protein daging pada ayam arab petelur yang diberi ransum menggunakan Azolla microphylla. J. Anim. Agr. 2 (1): 18 - 27

Marzuki, A. dan B. Rozi. 2018. Pemberian pakan bentuk cramble dan mash 
terhadap produksi ayam petelor. J. Il. Inovasi. 18 (1): 29 - 34

Muharlien, E. Sudjarwo, A. Hamiati dan H. Setyo. 2017. Ilmu Prduksi Ternak Unggas. Universitas Brawijaya Press, Malang.

Natsir, W. N. I., R. S. Rahayu, M. A. Daruslam, dan M. Azhar. 20 Palatabilitas maggot sebagai pakan sumber protein untuk ternak unggas. J. Jurnal Agrisistem. 16 (1): $27-32$

Priastoto, D., T. Kurtini, dan Sumardi. 2016. Pengaruh pemberian probiotik dari mikroba lokal terhadap performa ayam petelur. J. Il. Pet. Ter. 4 (1): $80-85$

Purwaningsih, D. L. 2014. Peternakan ayam ras petelur di kota Singkawang. J. mah. Ars. Universitas Tanjungpura. 2 (2): 7488

Risnajati, D. 2014. Pengaruh jumlah ayam per induk buatan terhadap performan ayam petelur strain Isa Brown periode starter. J. Sains Peternakan. 12 (1): 10 - 14

Samadi, S. Wajizah, dan F. Khairi. 2020. Formulasi pakan ayam arab petelur dan pembuatan imbuhan pakan berbasis sumber daya lokal di Kabupaten Aceh Besar. J. Med. Kon. Tani. Ter. 2 (1) : 25 32.

Siahaan, N. B., E. Suprijatna dan L.D. Mahfudz. 2013. Pengaruh penambahan tepung jahe merah (Zingiber officinale var. Rubrum) dalam ransum terhadap laju bobot badan dan produksi telur ayam kampung periode layer. J. Anim. Agr. 2 (1): $478-488$

Tamzil, M. H. dan B. Indarsih. 2020. Profil peternakan ayam ras petelur dan analisa faktor pemicu belum tercapainya swasembada telur konsumsi di Nusa
Tenggara Barat. J. Ilm. dan Tek. Pet. Ind. $6(1): 1-9$

Varianti, N. I., U. Atmomarsono, dan L. D. Mahfudz. 2017. Pengaruh pemberian pakan dengan sumber protein berbeda terhadap efisiensi penggunaan protein ayam lokal persilangan. J. Agripet. 17 (1) : $53-59$.

Walukow, K. S., J. Laihad, J. R. Leke, dan M. Montong. 2017. Penampilan produksi ayam ras petelur $\mathrm{mb} 402$ yang diberi ransum mengandung minyak limbah ikan cakalang (Katsuwonus pelamis L). J. Zootek. 37(1): 123 - 134

Widyantara, P. R. A., G.A.M. Kristina Dewi, dan I N. T. Ariana. 2017. Pengaruh lama penyimpanan terhadap kualitas telur konsumsi ayam kampung dan ayam Lohman Brown. J. Il. Pet. 20 (1): 5 - 11

Wijaya, Y., E. Suprijatna, dan S. Kismiati. 2017. Penggunaan limbah industri jamu dan bakteri asam laktat (Lactobacillus $s p$.) sebagai sinbiotik untuk aditif pakan terhadap kualitas interior telur ayam ras petelur. J. Pet. Ind. 19 (2): $47-54$

Wulandari, E. C., W. Murningsih, dan H. I. Wahyuni. 2012. Deposisi kalsium dan phosphor pada cangkang telur ayam arab dengan pemberian berbagai level Azolla microphylla. J. Anim. Agc. 1 (1): $507-520$

Yuwanta, T. 2004. Dasar Ternak Unggas. Kanisius, Yogyakarta.

Zahra, A. A., D. Sunarti, dan E. Suprijatna. 2012. Pengaruh pemberian pakan bebas pilih (free choice feeding) terhadap performans produksi telur burung puyuh. (Coturnix Coturnix Japonica). J. Anim. Agc. 1: 1 - 11 